Review Article

\title{
The Potential of Cellulose as a Source of Bioethanol using the Solid Catalyst: A Mini-Review
}

\author{
Didi Dwi Anggoro*, Kamsi Nur Oktavia \\ Department of Chemical Engineering, Faculty of Engineering, Diponegoro University, Semarang, \\ Central Java, 50275, Indonesia.
}

Received: 17th March 2021; Revised: $5^{\text {th }}$ July 2021; Accepted: $6^{\text {th }}$ July 2021

Available online: 8th July 2021; Published regularly: September 2021

\section{Abstract}

One of the most important biofuels is cellulose ethanol which is a popular material for bioethanol production. The present cellulosic ethanol production is through the cellulolytic process and this involves the splitting of complex cellulose into simple sugars through the hydrolysis process of the lignocellulose pretreated with acids and enzymes after which the product is fermented and distilled. There are, however, some challenges due to the enzymatic and acid processes based on the fact that acid hydrolysis has the ability to corrode equipment and cause unwanted waste while the enzymatic hydrolysis process requires a longer time because enzymes are costly and limited. This means there is a need for innovations to minimize the problems associated with these two processes and this led to the application of solid catalysts as the green and effective catalyst to convert cellulose to ethanol. Solid catalysts are resistant to acid and base conditions, have a high surface area, and do not cause corrosion during the conversion of the cellulose due to their neutral pH. This review, therefore, includes the determination of the cellulose potential as feedstock to be used in ethanol production as well as the preparation and application of solid catalyst as the mechanism to convert cellulose into fuel and chemicals.

Copyright (C) 2021 by Authors, Published by BCREC Group. This is an open access article under the CC BY-SA License (https://creativecommons.org/licenses/by-sa/4.0).

Keywords: Cellulose; Bioethanol; Solid catalyst; Hydrolysis

How to Cite: D.D. Anggoro, K.N. Oktavia (2021). The Potential of Cellulose as a Source of Bioethanol using the Solid Catalyst: A Mini-Review. Bulletin of Chemical Reaction Engineering \& Catalysis, 16(3), 661-672 (doi:10.9767/bcrec.16.3.10635.661-672)

Permalink/DOI: https://doi.org/10.9767/bcrec.16.3.10635.661-672

\section{Introduction}

The most crucial factor of production throughout the world is energy with most discovered to be produced from non-renewable sources. The main chemical source is fossil [1] which has been reported to be causing several environmental damages in many countries [2]. Some other problems associated with fossil fuels include instability of prices, supply risk, undersupply, and production of significant carbon emissions [3]. Moreover, global climate change

\footnotetext{
* Corresponding Author.

Email: anggorophd@gmail.com (D.D. Anggoro)
}

has led to the development of renewable biomass fuels and chemicals as one of the solutions to reduce the negative environmental impact of conventional fuels $[4,5]$. The production and utilization of liquid biofuels such as bioethanol and biodiesel have attracted interest in recent decades as a better substitute for fossil fuels. Indonesia is, therefore, one of the countries developing liquid biofuels as alternative energy. The country focuses on agriculture and this means it has the potential to be the highest producer of biofuel globally by prioritizing biomass through the use of cassava, sugar cane, corn, nira, and sago as the feedstock for bioethanol production [6]. This is important due to the ability of re- 
newable energy produced from plant-based biomass material to reduce negative impacts on the environment as well as the dependence on the use of fossil fuels [7]. Liquid biofuels are currently made almost totally from sugar, starch, or fats and oils derived from the plants used for feed and food. Meanwhile, the usage of these products as the raw materials to produce bioethanol reduces their availability and this led to a debate between the importance of their use for food or feed production. Therefore, ethanol factories introduce new regulations and laws to reduce the use of raw materials derived from food in ethanol production [8-11]. Moreover, feedstock inventory also indicates potential restrictions of demand for these materials. This also leads to the suggestions of new laws and guidelines to push the ethanol plants towards coordinating their development away from food-based feedstock, thereby, causing a few vulnerabilities concerning tentative arrangements [12]. Meanwhile, lignocellulosic biomass has the ability to provide certain environmental, economic, and strategic benefits for bioethanol production than the first-generation starch and sucrose [13] and it is obtainable from several sources, such as agriculture through corn and straw, wood processing mill residues, grasses, and woody crops [14].

Cellulose is, however, the most dominating component derived from plants with $30-55 \%$ followed by hemicellulose with $25-30 \%$ and lignin with 25-30\% (wt\%) [15]. Furthermore, cellulose is defined as a glucose polymer with a linear chain which is connected by $\beta$-1.4-glycosidic bond [16]. It is important to note that researchers from different countries have shown interest in the application of straws and other plant wastes as lignocellulosic biomass in converting cellulose into cellulosic ethanol. This led to the discovery of the pre-treatment, hydrolysis to sugars, fermentation, and distillation as the four primary steps for cellulosic ethanol production $[17,18]$. The pretreatment process is mainly to ensure the reduced compounds such as lignin have the ability to inhibit hydrolysis. There are two techniques usually used in the hydrolysis of lignocelluloses and these include enzymatic or acidic methods after which they are fermented to bioethanol [19]. However, there are several problems associated with the use of homogeneous acids such as wastewater treatment, poor recyclability, and corrosion in reactors, while the enzymatic process is also expensive and has low efficiency [20]. Therefore, green chemistry is observed to be the best solution to these problems and this involves the use of solid acid which is considered profitable in converting cellulose to bioethanol and also has the ability to resolve some of these problems due to its efficient reactions [21]. This research, therefore, discusses the potential of cellulose as a feedstock in bioethanol production, utilization of solid catalyst, and the conversion mechanism.

\section{Potential of Cellulose as Feedstock in Bioethanol Production}

The use of lignocellulose as raw material in bioethanol production is sustainable and attractive. This material is abundant in nature especially in forestry waste, plantation, and agricultural products, thereby, making it one of the energy sources required for the physical, chemical, and biological conversion processes. Meanwhile, the conversion of lignocellulose to ethanol is one of the most sought-after processes, and the six main groups of raw materials usually used include: (1) harvest residue including rice hulls, cane, sugary sorghum bagasse, corn stover, dissimilar straw types, and pulp; (2) softwood, such as spruce and pine; (3) public solid waste; (4) hardwood; (5) switchgrass; and (6) cellulose waste which is in the form of recycled paper waste and slurry [7]. Cellulose, however, represents the highest proportion by weight of lignocellulosic with 30 $55 \%$ relative to lignin with $25-30 \%$ and hemicellulose $25-30 \%$ [15]. It is possible to convert both cellulose and hemicellulose to ethanol after undergoing some processes including pretreatment, hydrolysis, and fermentation [2224]. Meanwhile, sugarcane and cassava are the major raw materials for bioethanol production in Indonesia while the other potential celluloses to be used as feedstock include oil palm empty fruit bunches, corn, grasses, and rice straw which is the most desirable due to their availability all-year-round.

Rice straw is small and varies according to the geographical area with a large percentage discarded each year. This material has the potential to be an energy source for future use due to its high cellulose and hemicellulose content and can also be readily hydrolyzed to fermentable sugars [25]. Furthermore, another material that can be used in manufacturing bioethanol is corn stover due to its high cellulose content and being the second-largest cereal crop after rice as indicated by the proportion of the area it is planted when compared with the total area for the food crops planted. Corn production continues to grow over the last decade at a rate of $1.22 \%$ per year. This means the continuous increase of its quantity makes it as- 
sessable potential biomass [26]. Meanwhile, the standard lignocellulosic raw materials include cellulose, lignin, and hemicellulose, which constitute a complex polymer structure that restricts near contact with cellulose through a reactive medium or estogetin [27]. Oil palm is one of the successor crops contributing significantly to Indonesia's economy by being one of the primary sources of foreign exchange in the country's non-oil and gas sector apart from rubber and cocoa. It is also important to note that Indonesia is the world's most important producer of palm oil with Crude Palm Oil (CPO) being the main product of its oil palm industries. The yield of this CPO is $20 \%$ while the empty fruit bunch fiber (EFB) is $21 \%$ and the moisture content is $>70 \%$. Oil Palm Empty Fruit Bunches (OPEFB) is a lignocellulosic biomass containing 41.3-46.5\% cellulose, 25.3-33.8\% hemicelluloses, and 27.6-32.5\%lignin content[22] as indicated in Table 1.

\section{Cellulose}

Herman Staudinger clarified the design of cellulose in 1920 and found it is comprised of D-glucose units connected to form long chains as shown in Figure 1. This means it consists of numerous glucose moieties connected in the structure of 6-D anhydrous glucopyranose units. Meanwhile, glycosidic spans bind the AGUs on the $\mathrm{C} 1$ and $\mathrm{C} 4$ carbon molecules [28, 29]. Therefore, cellulose is a crystalline and insoluble element due to its linear form [30].

\subsection{Physicochemical Properties of The Cellulose}

\subsubsection{Chemical properties}

Each cellulose glucosyl ring has three active hydroxyl groups which consist of one primary

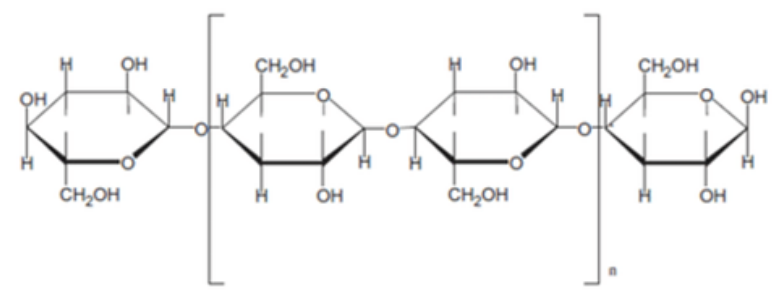

and two secondary hydroxyl groups. However, these hydroxyl groups also have the ability to bind intermolecular hydrogen which significantly influences the morphology and activity of the cellulose chains, especially the intermolecular hydrogen formed by the oxydryl at C3 and oxygen at adjacent molecular rings. Figure 1 shown the structure of cellulose, Moreover, the accessibility of cellulose depends on the difficulty of the reagent in reaching the hydroxyl and this concept is known as cellulose accessibility, while the ability of primary and secondary hydroxyls on the cellulose ring to react is referred to as cellulose reactivity. For example, toluene sulfonyl chloride is primarily esterified at the primary hydroxyl. Meanwhile, reversible reactions occur primarily at the hydroxyl group at $\mathrm{C} 6$ while irreversible reactions always take place at the hydroxyl group at $\mathrm{C} 2$ [31]. The degradation of cellulose is a significant reaction which can be used to generate cellulose products. This means the primary purpose of acid, microbial, and alkaline degradation is to break the glycosidic bonds between two adjacent glucose molecules. Furthermore, oxidative degradation occurs primarily to dissociate the hydroxyls at $\mathrm{C} 2, \mathrm{C} 3$, and $\mathrm{C} 6$ of the glucosyl ring, while the alkali peeling and oxidation-reduction reactions usually act on the reducing ends of the celluloses [32].

\subsubsection{Physical properties}

Cellulose has several visible physical properties and these include its white color, degradable, non-toxic, high tensile and compressive abilities. The physical attributes are further classified into morphology as well as thermal and electrical properties. The morphology focuses on determining the appearance and condition of the cellulose surface using Scanning Electron Microscopy (SEM) [33] and Transmission Electron Microscopy (TEM). The process involved dropping a tiny amount of nanocrystalline cellulose mixed in ethanol onto the substrates and kept in the air for about 15 minutes before drying with a hairdryer to ensure it is completely dry. The high bombardment of electron beams hitting the carbon tape

Figure 1. Structure of cellulose

Table 1. Properties of potential bioethanol feedstocks [25].

\begin{tabular}{lcccc}
\hline \multicolumn{5}{c}{ Composition (\%) } \\
\hline Cellulose & Rice Straw & Corn stover & OPEFB & Grasses \\
Hemicelluloe & $(32-47)$ & 38.2 & $(41.3-46.5)$ & $(25-40)$ \\
Lignin & $(19-27)$ & 25.8 & $(25.3-33.8)$ & $(35-50)$ \\
\hline
\end{tabular}


surface caused it to wrinkle to produce unclear morphologies of both nanospheres and nanorods as shown in Figure 2a. This image is slightly crisper in TEM as shown in Figure 2b. The cellulose nanospheres discovered have an average diameter of $50 \mathrm{~nm}$ while the cellulose nanorods have a width of $10-15 \mathrm{~nm}$ and length of $100 \mathrm{~nm}$ and were observed to be a little hazy because they were still dispersed throughout the residual amorphous phase. The two forms of morphology were developed from a single application of alkalization and bleaching as presented in Figure 2 [34].

The specific heat of a material is the amount of heat in calories required to deliver a temperature of 1 gram of material by $1{ }^{\circ} \mathrm{C}$. Moreover, the ability of a material to conduct heat due to the transmission of molecular vibrations from one atom or molecule to another depends on its chemical content. Heat properties and degradation of cellulose samples have generally been determined using thermogravimetric analysis (TGA). This method has been used in recent decades as a means of rapid evaluation of heat stability [35]. It has also been applied to lignocellulosic components by determining the change in sample weight by heat treatment at a certain increase in the degree of temperature and cellulose was found to have good stability. Thermal degradation usually only occurs at temperatures above $200{ }^{\circ} \mathrm{C}$, while the presence of crystalline areas in the cellulose has been discovered to have the ability to improve the stability of wood [36]. Hernández-Flores et al. [37] also reported that degradation behavior is typical of cellulose and its derivatives as indi-
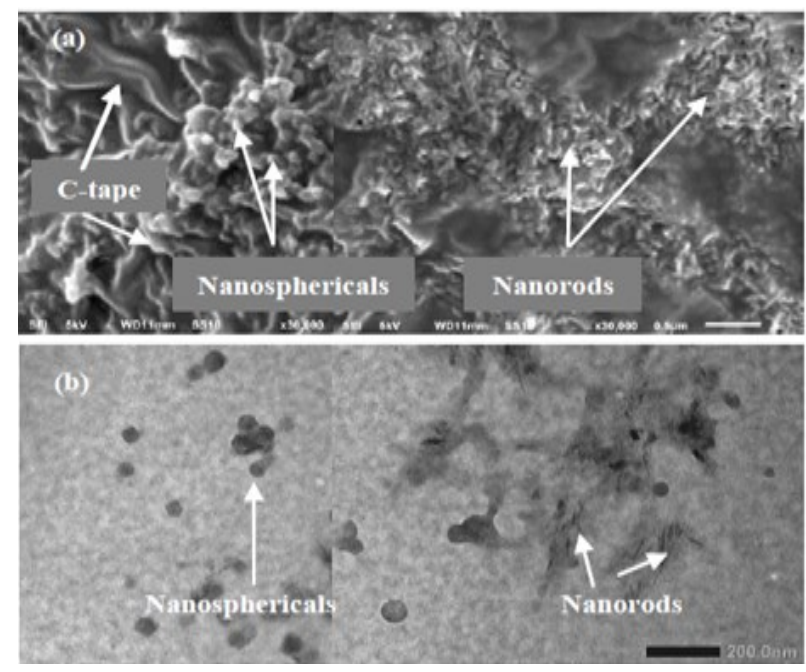

Figure 2. (a) SEM image of nanocrystalline cellulose prepared on a C-tape which dried imperfectly and (b) TEM image of the same specimen. Adapted from reference [34]. cated by a sharp decrease at the beginning of the degradation temperature up to the period it reaches a plateau. The residue was found to be approximately $11 \%$ at $400{ }^{\circ} \mathrm{C}$ due to levoglucosan which is a cellulose degradation product. Furthermore, TGA indicates the film has some humidity which reduces the dielectric strength by allowing electrical current to pass through the water molecules in the film. The reduction of this humidity content, therefore, improves the dielectric strength with the final residue recorded to be containing approximately 22 wt\% [37].

\section{Solid Catalysts}

A catalyst is a substance added to a reaction system to speed up its process. It provides active sites which function to bring reactants together and donate heat energy to ensure the reactant molecules pass the activation energy more efficiently [38]. Catalysts also play a vital role in converting biomass into chemicals and fuels [39] and also have the ability to improve production efficiency in the chemical industry by synthesizing more than $70 \%$ of the production process organically and inorganically [40]. Several solid catalyst systems have been used recently for the efficient conversion of biomass feedstocks into high-value fuels and chemicals [41].

Heterogeneous catalysts are, however, more desirable than homogeneous ones due to the ease with which they can be separated from the product to be reused [42]. Their development has also been historically through trial and error. Moreover, the process of synthesizing ammonia in the 1900s is through empirical screening which produces catalytic solid process $[43,44]$. This means solid-phase catalysts and gas-phase reactants are usually heterogeneous $[45,46]$. Furthermore, the heterogeneous catalysts in composite materials are characterized by volume and distribution of pores, surface area, relative amounts of different components including active species, physical promoters, and supports as well as the shape and volume [47]. Solid catalysts are categorized into four based on the relationship between their structures and properties of substrate activation and these include metal oxide, supported metal catalyst, micro-and mesoporous materials, and sulfonated polymers [48].

\subsection{Metal Oxides}

One of the most common catalysts used in industrial applications is metal oxide which is classified as inorganic materials with different 
potential applications as sensors, catalysts, fuel cells, and others [49]. Metal oxides and phosphates have Brønsted and Lewis acid sites on either the surface which also function as an active catalyst to different organic reactions. They consist of elements in groups IV and V with Zinc oxide $(\mathrm{ZnO})$, titanium oxide $\left(\mathrm{TiO}_{2}\right)$, tungsten oxide $\left(\mathrm{WO}_{3}\right)$, tin oxide $\left(\mathrm{SnO}_{2}\right)$, cuprous oxide $\left(\mathrm{Cu}_{2} \mathrm{O}\right)$, and cadmium oxide $(\mathrm{CdO})$ observed to be metal oxides [50,51].

\subsection{Supported Metal Catalyst}

The supported metal oxide catalysts consist of at least one active portion of metal oxide distributed on an oxide support surface. The active oxides are indeed transitional metal oxides through transitional aluminas, such as favored g- $\mathrm{Al}_{2} \mathrm{O}_{3}, \mathrm{SiO}_{2}, \mathrm{TiO}_{2}$ (anatase), $\mathrm{ZrO}_{2}$ (tetragonal), and carbons which are usually classified as support oxides [20,52].

\subsection{Micro- and Mesoporous Materials}

A significant amount of zeolitic hierarchical material has materialized over the last ten years and can be narrowly divided into two kinds which are hierarchical and composite zeolites. The hierarchical ones (HZs), however, involve a process where a large mesoporosity fraction of pure zeolite is combined with the original microporosity [53]. Zeolite is an aluminate crystal consisting of $\mathrm{SiO}_{4}$ and $\mathrm{AlO}_{4}$ tetrahedral as a constructing block and which are related by sharing one oxygen atom among two tetrahedral to form a 3D skeleton with a uniform pore dimension of molecular dimensions which is usually $0.25-1 \mathrm{~nm}$. Approximately 20 zeolites are included, such as: Y (FAU), ZSM-5 (MFI), mordenite (MOR), beta (BEA), MCM-22 (MWW), and several others which have been applied as heterogeneous catalysts in a variety of industrial processes including catalytic fluid breakdown (FCC), alkylation, methanol-tohydrocarbons (MTH), and hydro-conversion processes [54,55].

\subsection{Sulfonated Polymers}

The utilization of polymer ion-exchange resins is beneficial in sharing industrial transformations. Khatri et al. [19] explained that the selective dehydration of xylose into furfura lusing solid catalysts produced both good and very good reaction conditions. The sulfonated activated carbon catalyst is the better sulfonated polymer used in impregnating the carbon composite. Moreover, the P-C-higher $\mathrm{SO}_{3} \mathrm{H}$ 's catalytic activity is possibly due to the even distribution of polycyclic aromatic moieties along with the resin network which further leads to more sulfonation sites and higher sulfonic acid density relative to $\mathrm{C}-\mathrm{SO}_{3} \mathrm{H}$ in $\mathrm{P}-\mathrm{C}-\mathrm{SO}_{3} \mathrm{H}$ [19].

\section{Preparation of Catalyst}

\subsection{Impregnation Method}

This is the most common and easy method of preparing catalysts. It involves filling the pore with a metal salt solution at a sufficient concentration to provide proper loading [56]. Moreover, the addition of active phase precursor solution was 1.5 times significant than the support pore volume in wet impregnation. This method has the ability to produce a large amount of active phase precursor deposition on the outside of the support after the drying process. This further causes active phase distribution which helps reduce the penetration of reactants into the catalyst, thereby, increasing the activity of the catalyst. Wet impregnation is by far the most widely used method in preparing heterogeneous catalysts and this is due to its limited amount of waste, low cost, and simple technique $[57,8]$.

\subsection{Sol-gel}

Sol-gel is commonly used to describe the preparation of ceramic materials through several stages which involve the manufacture of a sol, sol gelation, and liquid phase removal. Sol is a colloidal suspension in which the dispersed phase is a solid undergoing Brownian motion or Brownian diffusion while the dispersion is a liquid. The gel is, however, a solid metric which encapsulates the solvent and needs to be dried for the solvent to be removed. Meanwhile, the time between gelling and drying is known as curing which is an important parameter. Therefore, sol-gel is a method with an attractive synthetic approach to design advanced catalytic formulations based on metals and metal oxides with a high degree of structural and compositional homogeneity. It is currently derived from hydrolysis and condensation of metal alkoxides but has several interesting strategies in preparing materials from the precursor solution level. Some of its advantages include low chemical temperature and the high surface-to-volume ratio of the products [56,59-61].

\subsection{Precipitation and Coprecipitation}

A catalyst manufacturing technique which produces high-performance catalysts is required to balance high production costs against the solid reaction rate in catalyst preparation. Precipitation is, however, the most commonly 
used method of preparing different catalytically relevant materials especially the support ones. This method is beneficial due to its ability to produce very pure materials and the flexible quality of the final product. Meanwhile, the coprecipitation method is usually used in preparing more than one component. It is defined as the simultaneous deposition of typically soluble parts with macro components through the same solution to form a crystalline mixture through adsorption, occlusion, or mechanical entrapment. The co-precipitation term is, however, is usually used generally in catalyst preparation technology [62].

\section{Conversion of Cellulose into Ethanol Using Solid Catalyst}

Glucose can be produced from cellulose through the hydrolysis process of a molecule due to air binding which produces smaller molecules. The most widely-used cellulosic biomass hydrolysis methods are categorized into two which are enzymatic and acid which also have certain drawbacks [63]. Glucose is a vital platform compound and this means its production from cellulose is an essential step in its valueadded phase [64]. Much attention has been directed to the hydrolysis of cellulose into sugar before fermentation with a solid acid. This is associated with several benefits of solid catalysts over liquid ones, such as: recyclability, easy separation, and minor reactor damage. They also reduce emissions with limited environmental effects [21].

Many researchers are currently developing reusable solid acid catalysts as substitutes for such non-recyclable systems. For example, carbon acid catalyst has the ability to form glycerol in rice straw provided with initial treatment

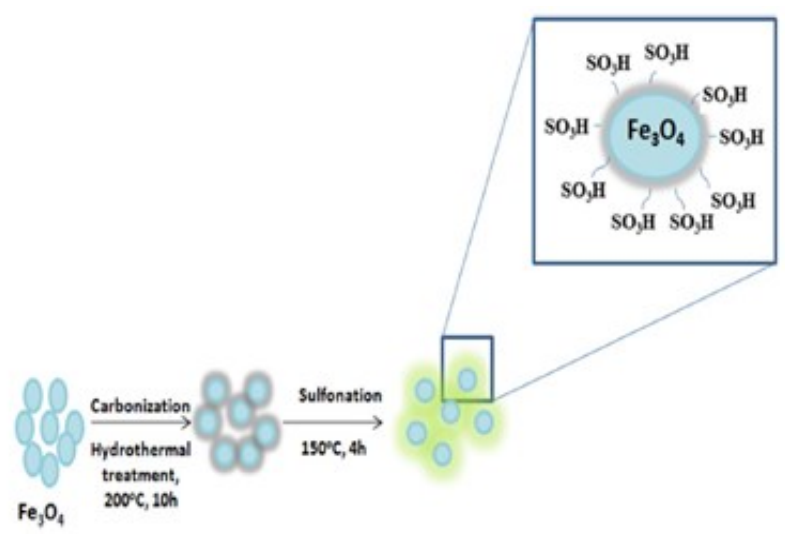

Figure 3. Illustration of synthesis of magnetic carbonacid catalyst $\left(\mathrm{Fe}_{3} \mathrm{O}_{4} @ \mathrm{C}-\mathrm{SO}_{3} \mathrm{H}\right)$. Adapted from reference [66]. by Goswami et al. [65] with an efficiency of $31 \%$ and a sugar yield of $262 \mathrm{mg} / \mathrm{g}$ at almost the same time. Moreover, the earliest concentration through the process of lyophilization and ethanol fermentation was found to be $2.28 \%$ glucose [65]. Lakshimi [66] also reported that the magnetic carbon-synthesized acid catalysts used in the production of bioethanol in unprofitable hydrolysis of pomegranate peel include $\mathrm{COOH},-\mathrm{OH}$, and $-\mathrm{SO}_{3} \mathrm{H}$ (Punica granatum) types.

The experimental result showed the influence of temperature, reaction time, and catalyst quantity on biomass hydrolysis. The expansion of $150 \mathrm{mg}$ was recorded for impetus measurement, while 58\% TRS yield was accomplished at $140{ }^{\circ} \mathrm{C}$ for two hours response time in a water medium. Moreover, the magnetic carbon acid catalyst was recovered by the outer attractive field of the response framework and reused for up to three continuous runs with minor action misfortunes. Preparation of magnetic carbon acid catalyst can be seen in Figure 3. The morphology of the synthesized catalyst showed that a carbon shell with a different structure of $\mathrm{Fe}_{3} \mathrm{O}_{4} @ \mathrm{C}-\mathrm{SO}_{3} \mathrm{H}$ has the potential to hydrolyze the biomass formed. Meanwhile, the regenerated catalyst activity in hydrolysis results in a reduction in total sugar yield due to the loss of some catalysts [25].

The lignocellulosic biomass saccharification of monosaccharides was found to be intermediate green energy due to the possibility of fermenting monosaccharides further into bioethanol. Most of the research cited on the saccharification process by solid acid used pure cellulose as the substrate. Moreover, the use of cellulosic biomass such as rice straw has attracted a great deal of consideration due to its abundance, low cost, and ability to tackle fuel challenges [67]. Sukma et al. [68] reported that the two-stage development of solid-acid catalystbased saccharification of rice straw is directed towards efficient bioethanol production. The effective catalyst used in the first step was Amberlyst 35 Dry which produced high yields of C6 monosaccharide with $47.2 \%$ and C5 monosaccharide with $10.8 \%$ at $130{ }^{\circ} \mathrm{C}$ for 30 minutes. A total of $65 \%$ sugar yield was also sequentially obtained and this means the proposed process has the capacity to improve the cost-effectiveness of bioethanol production in an environmentally responsible manner [68].

\subsection{Direct Conversion of Cellulose to Ethanol}

One of the most significant challenges currently being faced is the production of fuels and 
basic chemicals from biomass. This has little to do with "runaway crude oil." It focuses more on the production of liquid fuels from coal which is an industrial reality and profitable when compared to the current crude oil prices. It is also important to note that the search for crude oil and gas in remote areas of the world is not a solution but an aggravating factor. There are, however, theoretically more than enough biomass to satisfy global energy needs. This is indicated by the fact that only approximately $2.5 \%$ of the 165 billion tons of biomass produced each year is used by humans. Unfortunately, there is no "appropriate" biomass with the first-generation biofuels observed to be produced from plant oils, sugar, and starch. Moreover, several other pathways have been proposed but this current research is focused on cellulose-to-ethanol fermentation but this route is unsuitable due to the fact that ethanol is far from an ideal fuel.

At least half of the energy content of $1 \mathrm{~L}$ of gasoline by ethanol is consumed to produce energy along the chain ranging from agriculture to harvesting, processing, and treatment of the by-products [69]-[71]. This makes it important to determine the possibility of producing other biofuels and basic chemicals from cellulose without fermenting the material and through the use of the least amount of energy. Song et al. [72] recently made an intriguing proposal based on their discovery of a practical method to convert cellulose into high yield ethanol. It can be shown in Figure 17 for the route for direct synthesis of cellulose into ethanol in water in Scheme 1 [72].

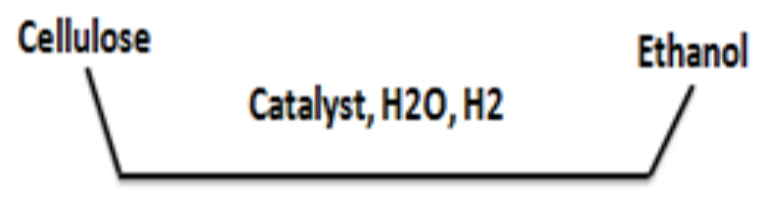

Scheme 1. Conversion of cellulose into ethanol. Adapted from reference [72].
The direct conversion of cellulose to ethanol necessitates the activation and cleavage of specific C-C and C-O bonds. Tungsten-based compounds such as tungstic acid $\left(\mathrm{H}_{2} \mathrm{WO}_{4}\right)$, four tungsten oxide 5 [73], and tungsten carbide 6 have, however, catalyzed the rupture of C-C bonds in glucose and the monomeric unit of cellulose to form $\mathrm{C} 2$ products. The superior performance of these tungsten-based compounds in the cleavage of cellulose C-C bonds led to the belief that it is possible to extract ethanol from cellulose using a combination of tungsten compounds and a catalyst with the ability to facilitate the selective hydrogenolysis of $\mathrm{C}-\mathrm{O}$ bonds in polyols.

For the first time, the direct synthesis of ethanol from cellulose using zirconia-supported Pt nanoparticles $\left(\mathrm{Pt} / \mathrm{ZrO}_{2}\right)$ [74] in an aqueous medium under $\mathrm{H}_{2}$ was reported. The $\mathrm{H}_{2} \mathrm{WO}_{4} \mathrm{Pt} / \mathrm{ZrO}_{2}$ combination was discovered to have the ability to catalyze the direct conversion with a $32 \%$ yield. The $\mathrm{H}_{2} \mathrm{WO}_{4}$ primarily facilitated the cleavage of $\mathrm{C}-\mathrm{C}$ bonds in the glucose unit while the $\mathrm{Pt} / \mathrm{ZrO}_{2}$ at an appropriate fraction of $\mathrm{Pt}^{0}$ and $\mathrm{Pt}^{2+}$ promoted the formation of ethanol via selective $\mathrm{C}-\mathrm{O}$ bond activation [72]. However, the insolubility of the polymer in water or other common reaction media makes the heterogeneously catalyzed hydrolysis of cellulose remains a complex process. This, therefore, leads to the frequent use of acidic or basic additives. Furthermore, the deoxygenation processes or hydrogenolysis allow the reduction of the oxygen content in lignocellulosic biomasses while simultaneously adding $\mathrm{H}_{2}$. This means there is likely the possibility to promote, in a novel step, the conversion of cellulose into short polyols and alcohols through the tandem hydrolysis/hydrogenolysis reaction, which is regarded as a vital tool to obtain highvalue-added products from biomass-based feedstocks. Meanwhile, one of the primary disadvantages of the cellulose hydrogenolysis process is the use of high-pressure molecular hydrogen such as the metal catalysts used in the

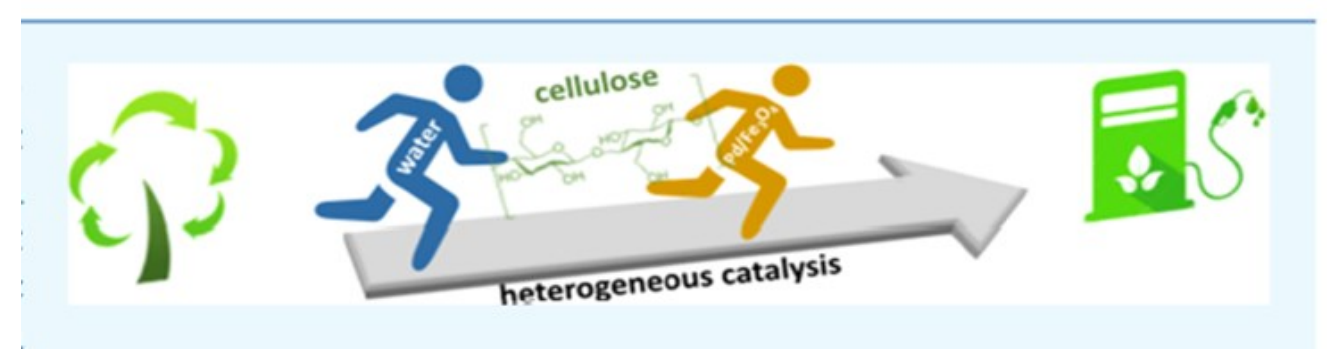

Scheme 2. The direct conversion of untreated microcrystalline cellulose into $\mathrm{C} 2 \mathrm{C} 3$ alcohols in a one-pot process facilitated by a heterogeneous bimetallic $\mathrm{Pd} / \mathrm{Fe}_{3} \mathrm{O}_{4}$ catalyst, Adapted from reference [78]. 
conversion of cellulose in the presence of molecular $\mathrm{H}_{2}$ [15,75-77]. Therefore, Gumina [75] developed a new heterogeneous catalytic process for the conversion which avoids the energyintensive pretreatment, high initial hydrogen pressure, truly unique solvents, and horrible hydrolysis conditions, this conversion process illustrate in Scheme 2 .

This process is self-sustaining and primarily selective for ethanol without using external molecular hydrogen or acid/basic promoters. The conversion process was completed at $240{ }^{\circ} \mathrm{C}$ after 12 hours with an ethanol molar selectivity of $51 \%$ among liquid products. The synergistic effect of water which aids the chemical pretreatment of cellulose via the hydrolysis process and the $\mathrm{Pd} / \mathrm{Fe}_{3} \mathrm{O}_{4}$ catalyst which catalyzes the hydrogenolysis reaction driving the pattern of obtained products were also elucidated $[78,79]$. The influence of solid catalyst for direct conversion cellulose was summarized in Table 2.

\section{Conclusions and Future Recommenda- tions}

Biomass has a vital role in producing fuels and basic chemicals. Meanwhile, the current global challenge is not about "running out of crude oil" because there are enough fossil resources on earth to last a few hundred years but they need to be preserved for future generations. Moreover, the burning of fossil fuels increases the quantity of carbon dioxide in the atmosphere. Biomass is, however, very abundant with only $3 \%$ reported to have been utilized despite its potential to serve as the new fuel source. Several researchers are presently innovating the process of converting cellulose into fuel such as ethanol to produce an environmentally friendly fuel and one of the methods discovered is the application of solid catalysts such as metal oxide, $\mathrm{TiO}_{2}$, and zeolite. However, these catalysts discovered to be significant to the direct conversion of cellulose to ethanol include $\mathrm{Ru}-\mathrm{WO}_{\mathrm{x}} / \mathrm{HZSM}-5, \quad \mathrm{Pd} / \mathrm{Fe}_{3} \mathrm{O}_{4}, \quad$ and $\mathrm{Mo} / \mathrm{Pt} / \mathrm{WO}_{\mathrm{x}}$ catalysts as indicated by the production of a relatively high yield with a simpler process without going through fermentation. It is, therefore, recommended that further similar studies be conducted to ensure the realization of green chemistry.

\section{Acknowledgment}

This work supported by a source of funds other than the APBN DIPA Diponegoro University for the 2021 Fiscal Year. Number: 11828/UN7.6.1/PP/2021.

\section{References}

[1] Examiner, P., Price, E.O. (2010) (12) United States Patent. vol. 2, no. 12.

[2] Martins, F., Felgueiras, C., Smitkova, M., Caetano, N. (2019). Analysis of fossil fuel energy consumption and environmental impacts in european countries. Energies, 12(6), 1-11. DOI: $10.3390 /$ en12060964.

Table 2. Literatures review on converting cellulose to ethanol using solid catalysts.

\begin{tabular}{|c|c|c|c|c|}
\hline Raw biomass & Catalyst & Reaction condition & Ethanol production & Ref \\
\hline $\begin{array}{l}\text { Bagasse and } \\
\text { corn stalk }\end{array}$ & $\begin{array}{l}\text { multifunctional } \\
\text { Ru-WOx/HZSM-5 } \\
\text { catalyst }\end{array}$ & $\begin{array}{l}\text { - bagasse and corn stalk, and } \\
45.2 \mathrm{mg}, 34.9 \mathrm{mg} \text { at } 235^{\circ} \mathrm{C} \\
-3 \mathrm{MPa} \mathrm{H} \mathrm{H}_{2} \text { in } 10 \mathrm{~h}\end{array}$ & $53.7 \%$ yield & {$[13]$} \\
\hline $\begin{array}{l}\text { Microcrystalline } \\
\text { cellulose (MCC) }\end{array}$ & $\mathrm{Pd} / \mathrm{Fe}_{3} \mathrm{O}_{4}$ & $\begin{array}{l}\text { - } 10 \mathrm{~g} \text { of microcrystalline cellu- } \\
\text { lose (MCC) } \\
\text { - the reaction temperature } \\
\quad\left(180-240^{\circ} \mathrm{C}\right) \\
-\left(5 \text { bars of } \mathrm{H}_{2} \text { or } \mathrm{N}_{2}\right) \text { was }\end{array}$ & $51 \%$ among & {$[78]$} \\
\hline Cellulose & $\mathrm{H}_{2} \mathrm{WO}_{4}-\mathrm{Pt} / \mathrm{ZrO}_{2}$ & $\begin{array}{l}\text { - cellulose, } 0.20 \mathrm{~g} ; \text { catalyst: } \\
\mathrm{H}_{2} \mathrm{WO}_{4}, 0.05 \mathrm{~g} ; \\
\text { - } \mathrm{Pt} \text { loading, } 2.0 \mathrm{wt} \%, 0.10 \mathrm{~g} ; \\
\text { } \mathrm{H}_{2} \mathrm{O}, 20 \mathrm{~mL} ; \mathrm{P}\left(\mathrm{H}_{2}\right), 4 \mathrm{MPa} ; \\
\text { - Temperature, } 523 \mathrm{~K} \text {; time, } 5 \mathrm{~h}\end{array}$ & $32 \%$ yield & {$[72]$} \\
\hline Cellulose & $\begin{array}{l}\text { Multifunctional } \\
\text { Mo/Pt/WOx } \\
\text { catalyst }\end{array}$ & $\begin{array}{l}-\mathrm{T}=518 \mathrm{~K} \\
-\mathrm{P}=6 \mathrm{MPa} \mathrm{H}\end{array}$ & $43.2 \mathrm{C} \%$. & {$[80]$} \\
\hline
\end{tabular}


[3] Ogunsuyi, H.O., Olawale, C.A. (2021). Evaluation of Plantain Biomass (Musa paradisiaca L.), as Feedstock for Bio-Ethanol Production. Green Sustain. Chem., 11(02), 59-71. DOI: 10.4236/gsc.2021.112006.

[4] Aditiya, H.B., Mahlia, T.M.I., Chong, W.T., Nur, H., Sebayang, A.H. (2016). Second generation bioethanol production: A critical review. Renew. Sustain. Energy Rev., 66, 631653. DOI: 10.1016/j.rser.2016.07.015.

[5] Sheldon, R.A. (2014). Green and sustainable manufacture of chemicals from biomass: State of the art. Green Chem., 16(3), 950-963. DOI: 10.1039/c3gc41935e.

[6] Youngs, H., Somerville, C. (2012). Development of feedstocks for cellulosic biofuels. F1000 Biol. Rep., 4(1), 1-11. DOI: 10.3410/B410.

[7] Bušić, A., Morzak, G., Belskaya, H., Šantek, I. (2018). Bioethanol Production from Renewable Raw Materials and Its Separation and Purification: A Review. Food Technology Biotechnology, 56(3), 289-311. DOI: 10.17113/ftb.56.03.18.5546.

[8] Padella, M., O’Connell, A., Prussi, M. (2019). What is still limiting the deployment of cellulosic ethanol? Analysis of the current status of the sector. Appl. Sci., 9 (21), 4523. DOI: 10.3390/app9214523.

[9] Kang, Q., Appels, L., Tan, T., Dewil, R. (2014). Bioethanol from lignocellulosic biomass: Current findings determine research priorities. Sci. World J., 2014, 298153. DOI: 10.1155/2014/298153.

[10] Devarapalli, M., Atiyeh, H.K. (2015). A review of conversion processes for bioethanol production with a focus on syngas fermentation. Biofuel Res. J., 2(3), 268-280. DOI: 10.18331/BRJ2015.2.3.5.

[11] Robak, K., Balcerek, M. (2018). Review of second generation bioethanol production from residual biomass. Food Technol. Biotechnol., 56 ( 2 ), $174-187$. D O I : 10.17113/ftb.56.02.18.5428.

[12] Lennartsson, P.R., Erlandsson, P., Taherzadeh, M.J. (2014). Bioresource Technology Integration of the first and second generation bioethanol processes and the importance of by-products. Bioresour. Technol., 165, 3-8. DOI: 10.1016/j.biortech.2014.01.127.

[13] Li, C., Xu, G., Wang, C., Ma, L., Qiao, Y., Zhang, Y., Fu, Y. (2019). One-pot chemocatalytic transformation of cellulose to ethanol over Ru-WOx/HZSM-5. Green Chem., 21(9), 2234-2239. DOI: 10.1039/c9gc00719a.
[14] Wahlström, R.M., Suurnäkki, A. (2015). Enzymatic hydrolysis of lignocellulosic polysaccharides in the presence of ionic liquids. Green Chem., 17(2), 694-714. DOI: 10.1039/c4gc01649a.

[15] Li, G., Liu, W., Ye, C., Li, X., Si, C.L. (2018). Chemocatalytic Conversion of Cellulose into Key Platform Chemicals. Int. J. Polym. Sci., 2018, 4723573. DOI: 10.1155/2018/4723573.

[16] Rosales-Calderon, O., Arantes, V. (2019). A review on commercial-scale high-value products that can be produced alongside cellulosic ethanol. Biotechnology for Biofuels, 12(1), 240 (2019) DOI: 10.1186/s13068-019-1529-1

[17] Chin, K.L., Hng, P.S. (2013). A Real Story of Bioethanol from Biomass: Malaysia Perspective. In M.D. Matovic (Editor) Biomass Now Sustain. Growth Use. IntechOpen. DOI: 10.5772/51198.

[18] Ibrahim, H.A.H. (2012). Pretreatment of straw for bioethanol production. Energy Procedia, $14, \quad 542-551$. D O I : 10.1016/j.egypro.2011.12.973.

[19] Khatri, P.K., Karanwal, N., Kaul, S., Jain, S.L. (2015). Sulfonated polymer impregnated carbon composite as a solid acid catalyst for the selective synthesis of furfural from xylose. Tetrahedron Lett., 56(10), 1203-1206. DOI: 10.1016/j.tetlet.2015.01.116.

[20] Knözinger, H., Kochloefl, K. (2003). Heterogeneous Catalysis and Solid Catalysts. In Ullmann's Encycl. Ind. Chem., Wiley. DOI: 10.1002/14356007.a05_313.

[21] Guo, F., Fang, Z., Xu, C.C., Smith, R.L. (2012). Solid acid mediated hydrolysis of biomass for producing biofuels. Prog. Energy Combust. Sci., 38(5), 672-690. DOI: 10.1016/j.pecs.2012.04.001.

[22] Sudiyani, Y., Hermiati, E. (2010). Utilization of Oil Palm Empty Fruit Bunch (Opefb) for Bioethanol Production Through Alkali and Dilute Acid Pretreatment and Simultaneous Saccharification and Fermentation. Indones. J. Chem., 10(2), 261-267. DOI: 10.22146/ijc.21471.

[23] Sun, Y., Cheng, J. (2002). Hydrolysis of lignocellulosic materials for ethanol production: A review. Bioresour. Technol., 83(1), 1-11. DOI: 10.1016/S0960-8524(01)00212-7.

[24] Limayem, A., Ricke, S.C. (2012). Lignocellulosic biomass for bioethanol production: Current perspectives, potential issues and future prospects. Prog. Energy Combust. Sci., 38(4), 449-467. DOI: 10.1016/j.pecs.2012.03.002. 
[25] Juanssilfero, A.B., Djohan, A.C., Purnawan, A., Yopi, Y. (2015). Bioethanol production from Indica IR.64 rice straw biomass by direct saccharification and fermentation. Int. J. Adv. Sci. Eng. Inf. Technol., 5(1), 1-5. DOI: 10.18517/ijaseit.5.1.467.

[26] Parthasiwi, L.D., Kurniawan, D.A., Abhirama, N.G., Sudibyo, H., Pradana, Y.S. (2018). Evaluation of potential raw material for industrial scale bioethanol production in Indonesia. AIP Conf. Proc., 2026, 020039. DOI: $10.1063 / 1.5064999$.

[27] Zhao, Y., Damgaard, A., Christensen, T.H. (2018). Bioethanol from corn stover - a review and technical assessment of alternative biotechnologies. Prog. Energy Combust. Sci., 67, 275-291. DOI: 10.1016/j.pecs.2018.03.004.

[28] Huang, Y.B., Fu, Y. (2013). Hydrolysis of cellulose to glucose by solid acid catalysts. Green Chem., 15(5), 1095-1111. DOI: 10.1039/c3gc40136g.

[29] Delidovich, I., Leonhard, K., Palkovits, R. (2014). Cellulose and hemicellulose valorisation: An integrated challenge of catalysis and reaction engineering. Energy Environ. Sci., 7(9), 2803-2830. DOI: 10.1039/c4ee01067a.

[30] Abe, M.M., Branciforti, M.C., Brienzo, M. (2021). Biodegradation of hemicellulosecellulose-starch-based bioplastics and microbial polyesters. Recycling, 6(1), 2313-4321. DOI: 10.3390/RECYCLING6010022.

[31] Chen, H. (2014). Biotechnology of lignocellulose: Theory and practice. Springer, Netherlands. DOI: 10.1007/978-94-007-6898-7.

[32] Glaus, M.A., Van Loon, L.R. (2008). Degradation of cellulose under alkaline conditions: New insights from a 12 years degradation study. Environ. Sci. Technol., 42(8), 29062911. DOI: 10.1021/es7025517.

[33] Azeh, Y., Olatunji, G.A., Mamza, P.A. (2012). Scanning Electron Microscopy and Kinetic Studies of Ketene-Acetylated Wood/Cellulose High-Density Polyethylene Blends. Int. J. Carbohydr. Chem., 2012, 1-7. DOI: 10.1155/2012/456491.

[34] Sosiati, H., Muhaimin, M., Purwanto, P., Wijayanti, D.A., Triyana, K. (2014). Nanocrystalline Cellulose Studied with a Conventional SEM. In Proceedings of the 2014 International Conference on Physics, 12-15. Yogyakarta, Indonesia: International Conference on Physics 2014 (ICP-2014). DOI: 10.2991/icp-14.2014.3.

[35] Poletto, M., Ornaghi Júnior, H.L., Zattera, A.J. (2014). Native cellulose: Structure, characterization and thermal properties. Materials (Basel)., 7(9), 6105-6119. DOI: 10.3390/ma7096105.
[36] Chen, D., Gao, A., Cen, K., Zhang, J., Cao, X., $\mathrm{Ma}, \mathrm{Z}$. (2018). Investigation of biomass torrefaction based on three major components: Hemicellulose, cellulose, and lignin. Energy Convers. Manag., 169(17), 228-237. DOI: 10.1016/j.enconman.2018.05.063.

[37] Hernández-Flores, J.A., et al. (2020). Morphological and Electrical Properties of Nanocellulose Compounds and Its Application on Capacitor Assembly. Int. J. Polym. Sci., 2020, 1891064. DOI: 10.1155/2020/1891064.

[38] Ong, T.C., Verel, R., Copéret, C. (2016). Solidstate NMR: Surface chemistry applications. Encycl. Spectrosc. Spectrom., 11(494), 121127. DOI: 10.1016/B978-0-12-4095472.12130-4.

[39] Liu, B., Zhang, Z. (2016). Catalytic Conversion of Biomass into Chemicals and Fuels over Magnetic Catalysts. ACS Catal., 6(1), 326-338. DOI: 10.1021/acscatal.5b02094.

[40] van Santen, R. (2009). Future perspectives in catalysis. NRSC-Catalysis, p. 82, [Online]. Available: http://www.nrsc$\begin{array}{llllll}c & a & t & a & l & y\end{array}$ sis.nl/files/media/scientific_reports/Future_pe rspectives_in_Catalysis.pdf.

[41] De Jong, K.P. (2009) Synthesis of Solid Catalayst. In Krijn P. de Jong (Editor): Wiley . DOI: 10.1002/9783527626854.ch1.

[42] Friend, C.M., Xu, B. (2017). Heterogeneous catalysis: A central science for a sustainable future. Acc. Chem. Res., 50(3), 517-521. DOI: 10.1021/acs.accounts.6b00510.

[43] Norskov, J., Chen, J. (2016). Sustainable Ammonia Synthesis. Report, DOE Roundtable, pp. 1-23, [Online]. Available: https://www.osti.gov/biblio/1283146.

[44] Schlögl, R. (2003). Catalytic synthesis of ammonia - A 'never-ending story'?. Angew. Chemie - Int. Ed., 42(18), 2004-2008. DOI: 10.1002/anie. 200301553.

[45] Dumbre, D., Choudhary, V.R. (2020). Properties of functional solid catalysts and their characterization using various analytical techniques. In C.M. Hussain, P. Sudarsanam (Editors) Advanced Functional Solid Catalysts for Biomass Valorization. Elsevier Inc. DOI: 10.1016/B978-0-12-820236-4.00003-9

[46] Schlögl, R. (2015). Heterogeneous catalysis. Angew. Chemie - Int. Ed., 54(11), 3465-3520. DOI: 10.1002/anie.201410738.

[47] Campanati, M., Fornasari, G., Vaccari, A. (2003). Fundamentals in the preparation of heterogeneous catalysts. Catal. Today, 77(4), 299-314. DOI: 10.1016/S0920-5861(02)00375- 
9.

[48] Hara, M., Nakajima, K., Kamata, K. (2015). Recent progress in the development of solid catalysts for biomass conversion into high value-added chemicals. Sci. Technol. Adv. Mater., 16(3), 1-22. DOI: 10.1088/1468$6996 / 16 / 3 / 034903$.

[49] Védrine, J.C. (2017). Heterogeneous catalysis on metal oxides. Catalysts, 7(11), 341. DOI: 10.3390/catal7110341.

[50] Kumar, S., Saralch, S., Jabeen, U., Pathak, D. (2020). Metal oxides for energy applications. In S. Thomas, A.T. Sunny, P. Velayudhan (Editors) Colloidal Metal Oxide Nanoparticles-Synthesis, Characterization and Applications. Elsevier Inc. DOI: 10.1016/B978-0-12813357-6.00017-6

[51] Carrier, X., Royer, S., Marceau, E. (2018). Synthesis of metal oxide catalysts. In J.C. Védrine (Editor) Metal Oxides in Heterogeneous Catalysis. Elsevier Inc. DOI: 10.3390/ma12040668

[52] Gates, B.C. (2019). Atomically Dispersed Supported Metal Catalysts: Seeing Is Believing. Trends Chem., 1(1), 99-110. DOI: 10.1016/j.trechm.2019.01.004.

[53] Vu, X.H., Armbruster, U., Martin, A. (2016). Micro/mesoporous zeolitic composites: Recent developments in synthesis and catalytic applications. Catalysts, 6(12) 2016. DOI: 10.3390/catal6120183.

[54] Shi, J., Wang, Y., Yang, W., Tang, Y., Xie, Z. (2015). Recent advances of pore system construction in zeolite-catalyzed chemical industry processes. Chem. Soc. Rev., 44(24), 88778903. DOI: $10.1039 / \mathrm{c} 5 \mathrm{cs} 00626 \mathrm{k}$.

[55] Shao, H., Pinnavaia, T.J. (2010). Synthesis and properties of nanoparticle forms saponite clay, cancrinite zeolite and phase mixtures thereof. Microporous Mesoporous Mater., $133(1-3), \quad 10-17$. D O I : 10.1016/j.micromeso.2010.04.002.

[56] Louis, C. (2016). Chemical preparation of supported bimetallic catalysts. Gold-based bimetallic, a case study. Catalysts, 6(8), 183. DOI: 10.3390/catal6080110.

[57] Sietsma, J.R.A., van Dillen, A.J., de Jongh, P.E., de Jong, K.P. (2006). Application of ordered mesoporous materials as model supports to study catalyst preparation by impregnation and drying. In Studies in Surface Science and Catalysis, 162, 95-102. Elsevier Masson SAS. DOI: 10.1016/s0167-2991(06)808955
[58] Bhaskaruni, S.V.H.S., Maddila, S., Gangu, K.K., Jonnalagadda, S.B. (2020). A review on multi-component green synthesis of $\mathrm{N}$ containing heterocycles using mixed oxides as heterogeneous catalysts. Arab. J. Chem., $13(1), \quad 1142-1178$. D O I : 10.1016/j.arabjc.2017.09.016.

[59] Ciriminna, R., Fidalgo, A., Pandarus, V., Béland, F., Ilharco, L.M., Pagliaro, M. (2013). The sol-gel route to advanced silica-based materials and recent applications. Chem. Rev., 113(8), 6592-6620. DOI: 10.1021/cr300399c.

[60] Esposito, S. (2019). 'Traditional' sol-gel chemistry as a powerful tool for the preparation of supported metal and metal oxide catalysts. Materials (Basel)., 12(4), 1-25. DOI: 10.3390/ma12040668.

[61] Ward, D., Edmond, I. (1996). Preparing Catalytic Materials by the Sol-Gel Method. Ind. Eng. Chem. Res., 34(2), 421-433. DOI: 10.1021/ie00041a001.

[62] Schüth, F., Unger, K. (2008). Precipitation and Coprecipitation. In G. Ertl, H. Knözinger, J. Weitkamp (Editors) Preparation of Solid Catalysts, 60-84, John Wiley \& $\mathrm{S}$ o $\mathrm{n} \mathrm{s}, \quad \mathrm{I} \mathrm{n} \mathrm{c}$. D O I : 10.1002/9783527619528.ch3d.

[63] Baig, M.Z., Dharmadhikari, S.M., Ismail, S. (2017). Technological processes for conversion of lignocellulosic biomass to bioethanol. $J$. Pure Appl. Microbiol., 11(4), 1863-1881. DOI: 10.22207/JPAM.11.4.27.

[64] Wang, S., Sima, G., Cui, Y., Chang, L., Gan, L. (2020). Efficient hydrolysis of cellulose to glucose catalyzed by lignin-derived mesoporous carbon solid acid in water. Chinese $J$. Chem. Eng., 289(7), 1866-1874. DOI: 10.1016/j.cjche.2020.03.012.

[65] Goswami, M., Meena, S., Navatha, S., Prasanna Rani, K.N., Pandey, A., Sukumaran, R.K., Prasad, R.B.N., Prabhavathi Devi, B.L.A. (2015). Hydrolysis of biomass using a reusable solid carbon acid catalyst and fermentation of the catalytic hydrolysate to ethanol. Bioresour. Technol., 188, 99-102. DOI: 10.1016/j.biortech.2015.03.012.

[66] Hemalatha H., Lakshmi, A.B. (2020). Catalytic Hydrolysis of Fruit Waste Using Magnetic Carbon Acid Catalyst for Bioethanol Production. Waste and Biomass Valorization, 12, 971-983. DOI: 10.1007/s12649-020-01019$\mathrm{z}$.

[67] Li, S., Qian, E.W. (2011). Direct Saccharification of Rice Straw Using a Solid Acid Catalyst. Journal of the Japan Institute of Energy, 90(11), 1065-1071. DOI: 10.3775/jie.90.1065. 
[68] Sukma, L.P.P., Wang, X., Li, S., Nguyen, T.T., $\mathrm{Pu}$, J., Qian, E.W. (2019). Two-Step Saccharification of Rice Straw Using Solid Acid Catalysts. Ind. Eng. Chem. Res., 58(14), 56865697. DOI: 10.1021/acs.iecr.8b06473.

[69] Klaas, M.R.G., Schöne, H. (2009). Direct, high-yield conversions of cellulose into biofuel and platform chemicals - On the way to a sustainable biobased economy. ChemSusChem, 2(2), 127-128. DOI: 10.1002/cssc.200800186.

[70] Kamm, B., Gruber, P.R., Kamm, M. (2016). Biorefineries-Industrial Processes and Products. In Ullmann's Encycl. Ind. Chem., pp. 138. DOI: 10.1002/14356007.104_101.pub2.

[71] Coates, W. (2006). Book review. Ind. Crops Prod., $23(2), \quad 223-224$. D O I : 10.1016/j.indcrop.2005.06.002.

[72] Song, H., Wang, P., Li, S., Deng, W., Li, Y., Zhang, Q., Wang, Y. (2019). Direct conversion of cellulose into ethanol catalysed by a combination of tungstic acid and zirconia-supported Pt nanoparticles. Chem. Commun., 55, 43034306. DOI: 10.1039/C9CC00619B.

[73] Liu, Y., Luo, C., Liu, H., (2012). Tungsten trioxide promoted selective conversion of cellulose into propylene glycol and ethylene glycol on a ruthenium catalyst. Angew. Chemie - Int. Ed. , 51(13), 3249-3253. DOI: 10.1002/anie.201200351.

[74] Chen, X., Chen, J., Zhao, Y., Chen, M., Wan, H. (2012). Effect of dispersion on catalytic performance of supported pt catalysts for co oxidation. Chinese J. Catal., 33(11-12), 19011905. DOI: 10.1016/S1872-2067(11)60447-6.
[75] Yabushita, M., Kobayashi, H., Fukuoka, A. (2010). Catalytic transformation of cellulose into platform chemicals. Appl. Catal. B Environ., $145, \quad 1-9 . \quad$ D O I : 10.1016/j.apcatb.2013.01.052.

[76] Shrotri, A., Kobayashi, H., Fukuoka, A. (2018). Cellulose Depolymerization over Heterogeneous Catalysts. Acc. Chem. Res., 51(3), 761-768. DOI: 10.1021/acs.accounts.7b00614.

[77] Bali, G., Meng, X., Deneff, J.I., Sun, Q., Ragauskas, A.J. (2015). The effect of alkaline pretreatment methods on cellulose structure and accessibility. ChemSusChem, 8(2), 275279. DOI: $10.1002 /$ cssc.201402752.

[78] Gumina, B., Espro, C., Galvagno, S., Pietropaolo, R., Mauriello, F. (2019). Bioethanol Production from Unpretreated Cellulose under Neutral Selfsustainable Hydrolysis/Hydrogenolysis Conditions Promoted by the Heterogeneous $\mathrm{Pd} / \mathrm{Fe} 3 \mathrm{O} 4$ Catalyst. ACS Omega, 4(1), 352-357. D O I : 10.1021/acsomega.8b03088.

[79] Liao, F., Lo, T.W.B., Tsang, S.C.E. (2015). Recent Developments in Palladium-Based Bimetallic Catalysts. Chem CatChem, 7(14), 19982014. DOI: $10.1002 /$ cctc. 201500245 .

[80] Yang, M., Qi, H., Liu, F., Ren, Y., Pan, X., Zhang, L., Liu, X., Wang, H., Pang, J., Zheng, M., Wang, A., Zhang, T. (2019). One-Pot Production of Cellulosic Ethanol via Tandem Catalysis over a Multifunctional $\mathrm{Mo} / \mathrm{Pt} / \mathrm{WOx}$ Catalyst. Joule, 3(8), 1937-1948. DOI: 10.1016/j.joule.2019.05.020.

Selected and Revised Papers from International Conference on Sustainable Energy and Catalysis 2021 (ICSEC 2021) (https://engineering.utm.my/chemicalenergy/icsec2021/) (School of Chemical and Energy Engineering, Faculty of Engineering, Universiti Teknologi Malaysia, 16-17th February 2021) after Peer-reviewed by Scientific Committee of ICSEC 2021 and Peer-Reviewers of Bulletin of Chemical Reaction Engineering \& Catalysis.

Editors (Guest) in this ICSEC 2021 section are Nor Aishah Saidina Amin, Mohd Asmadi Mohammed Yussuf, Salman Raza Naqui, while Editor in Chief is I. Istadi. 